\title{
The effects of ruminal and duodenal casein infusion on dry matter (DM) intake of red clover silage and rumen pool size, digestion and passage kinetics of neutral detergent fibre (NDF)
}

\author{
H Khalili, P Huhtanen, S Jaakkola, T Varvikko
}

\author{
Agricultural Research Centre, Institute of Animal Production, 31600 Jokioinen, Finland
}

\begin{abstract}
The objective of this study was to investigate the effects of casein (300 $\mathrm{g} \mathrm{Na}$-caseinate in 6 I of water) infused continuously into rumen $(R)$, duodenum (D) or both (RD) on forage intake, milk yield, chewing activities, rumen pool size and, digestion and passage kinetics of NDF. Control diet $(C)$ consisted of red clover-timothy (75:25) silage fed ad libitum. Four ruminally and duodenally cannulated Ayrshire cows in their mid-lactation were used in a balanced $4 \times 4$ Latin square. The silage was made as directcut, and ensiled with a formic-acid based additive (5.8 l/tn). The silage (CP $168 \mathrm{~g} / \mathrm{kg} \mathrm{DM)}$ was well-preserved as indicated by a restricted fermentation with high sugar (109 $\mathrm{g} / \mathrm{kg}$ DM), and low of ammonia-N (29 g/ $\mathrm{kg} \mathrm{N})$ and lactic acid ( $5 \mathrm{~g} / \mathrm{kg}$ DM) contents. Chewing activities were estimated by visual observation every 5 $\min$ for $24 \mathrm{~h}$. Total collection of faeces was used. Manual evacuation of rumen contents were made on two consecutive days (6:00, $9: 30 \mathrm{~h}$ ) and the mean values were used to calculate rumen pool sizes and digestion kinetics of NDF (Robinson et al, 1987, Livest Prod Sci, 17, 37-62). To measure the potential digestibility of NDF of silage, rumen contents and faeces were incubated in nylon bags for $288 \mathrm{~h}$. Yb-labelled silage was used to estimate
\end{abstract}

digesta passage (samples from duodenum and rectum). Non-linear models without (G1G1) or with gamma time dependency ( $\mathrm{GnG} 1, \mathrm{n}=2$ to 4) in the first compartment were used to estimate digesta passage kinetics. Total mean retention time (TMRT) was calculated as $n / k_{1}+$ $1 / \mathrm{k}_{2}+$ transit time (Moore et al, 1992, J Anim Sci, 70, 3528-3540).

Ruminal casein infusion tended to increase $(P<0.08)$ and duodenal infusion increased $(P<0.05)$ silage $D M I$ and milk yield, the responses being almost additive. Total chewing time was longest on $D$ diets but there were no dietary effects on chewing time per $\mathrm{kg}$ NDF (mean $140 \mathrm{~min}$ ) or NDF digestibility (mean 0.566). R diets slightly decreased but $D$ clearly increased rumen pool size of NDF. R diets increased the values of $k_{p}$ of NDF and $k_{d}$ of potentially digestible NDF (DNDF) but D diets tended $(P<0.08)$ to decrease the value of $k_{p}$ of NDF. There was no effects on TMRT for duodenal sampling (mean $33.2 \mathrm{~h}$ ) but for faecal sampling $R$ and $D$ diets both decreased the TMRT values. In conclusion, the increase in silage DMI was associated with faster rates of passage $\left(k_{p}\right)$ and digestion $\left(k_{d}\right)$ with $R$ diets and with increased rumen fill with $D$ diets.

\begin{tabular}{|c|c|c|c|c|c|c|c|c|c|}
\hline Diet & $\begin{array}{c}\text { Silage } \\
(\mathrm{kg} \mathrm{DM})\end{array}$ & $\begin{array}{c}\text { Chewing } \\
(\mathrm{min} / \mathrm{d})\end{array}$ & $\begin{array}{c}\text { NDF } \\
\text { dig }\end{array}$ & $\begin{array}{c}\text { NDF } \\
\text { pool }(\mathrm{kg})\end{array}$ & $\begin{array}{l}\text { NDF } \\
\left(k_{p} / h\right)\end{array}$ & $\begin{array}{l}\text { DNDF } \\
\left(k_{d} / h\right)\end{array}$ & $\begin{array}{c}\text { TMRT }^{1} \\
\text { (h) }\end{array}$ & $\begin{array}{c}\text { TMRT2 }^{2} \\
\text { (h) }\end{array}$ & $\begin{array}{l}\text { Milk } \\
(\mathrm{kg})\end{array}$ \\
\hline C & 15.1 & 933 & 0.564 & 7.93 & 0.0159 & 0.0369 & 33.3 & 43.0 & 19.5 \\
\hline R & 15.4 & 955 & 0.563 & 7.89 & 0.0164 & 0.0400 & 33.4 & 40.2 & 20.4 \\
\hline D & 15.7 & 1018 & 0.569 & 8.59 & 0.0150 & 0.0360 & 34.4 & 41.0 & 21.2 \\
\hline $\mathrm{RD}$ & 16.0 & 975 & 0.566 & 8.16 & 0.0162 & 0.0395 & 31.8 & 39.7 & 21.8 \\
\hline SEM & 0.20 & 12.2 & 0.0068 & 0.074 & 0.00024 & 0.00106 & 0.79 & 0.18 & 0.40 \\
\hline$P<0.05$ & $\mathrm{D}$ & $\mathrm{D}, \mathrm{RD}$ & & $R, D, R D$ & $\mathrm{R}$ & $\mathrm{R}$ & & $\mathrm{R}, \mathrm{D}, \mathrm{RD}$ & D \\
\hline
\end{tabular}

SEM = standard error of the mean ; sampling site : ${ }^{1}$ duodenum, ${ }^{2}$ rectum 